\title{
Incidental bilateral optic nerve hypoplasia
}

\author{
Joshua Paul Harvey
}

Correspondence to

Dr Joshua Paul Harvey, harveyjoshua90@gmail.com

Accepted 23 May 2017

\section{DESCRIPTION}

A 19-year-old man was incidentally noted to have a bitemporal heteronymous hemianopia on automated perimetry during his first optician's sight test (figure 1). The patient reported life-long reduced vision in the right eye although this was his first presentation to ophthalmic services. The patient was induced at 34 weeks due to poorly controlled gestational diabetes in his mother. The patient had no other ocular, medical, drug or family history.

On examination, visual acuity was $6 / 9$ in the right eye and $6 / 6$ in the left eye. The anterior segment was normal. Funduscopy demonstrated bilateral hypoplastic optic discs with the characteristic 'double-ring sign' (figure 2). The disc diameter to disc-macula distance ratios were 0.33 and 0.31 in the right and left eyes, respectively (figure 3 ). There was no relative afferent pupillary defect, Ishihara testing was normal and there was no impairment of extraocular muscle function.

All blood tests including pituitary function tests were normal. MRI of the brain, orbits and pituitary showed bilaterally thin optic nerves but no other abnormality (figure 4). Electrodiagnostic tests were normal. The patient was discharged from follow-up after his field defect remained stable at 2 years after presentation.

Optic nerve hypoplasia (ONH) is a congenital abnormality of the optic nerve with an incidence of 10.9/100 000 per year. ${ }^{1}$ The pathophysiology of $\mathrm{ONH}$ is unknown; however, its aetiology has been linked to several maternal risk factors making an accurate gestational history extremely important. Associations that are relevant in this case report include young maternal age, primiparity, maternal smoking and gestational diabetes. ${ }^{2}$ Additional associations include maternal use of alcohol, recreational drugs, anti-depressants, anti-convulsants and anti-emetics. ${ }^{2}$

The classical clinical finding in $\mathrm{ONH}$ is of small optic nerve heads with a characteristic 'doublering sign'. This finding appears as a pale white/ yellow ring around the optic disc, which is thought
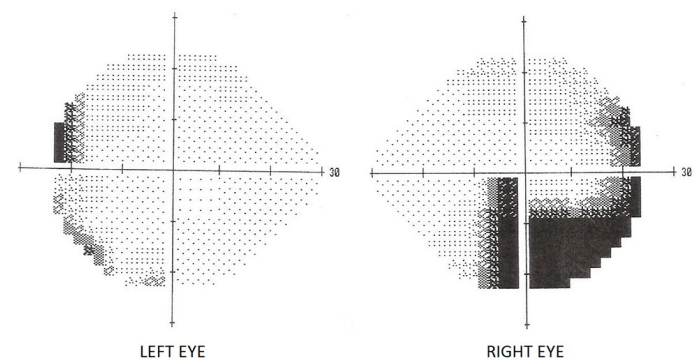

Figure 1 24-2 Humphrey Visual Field Test demonstrating a bitemporal heteronymous hemianopia.

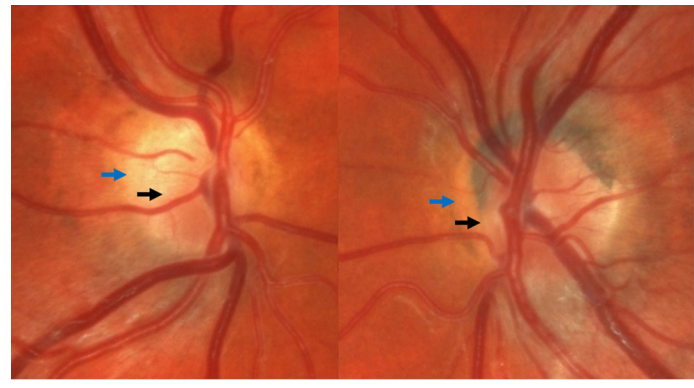

Figure 2 Magnified image of optic discs demonstrating the double-ring sign. Black arrow: optic nerve edge. Blue arrow: scleral canal edge.

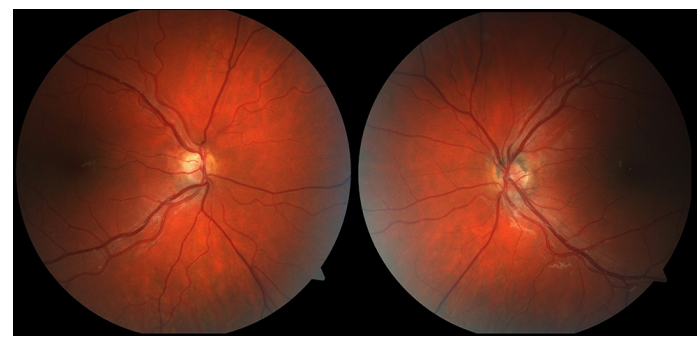

Figure 3 Colour photographs of the hypoplasic optic nerve heads demonstrating reduced disc diameter to discmacula ratios.

to represent the scleral canal. ${ }^{2}$ The ratio of disc diameter to disc-macula distance (measured from the temporal edge of the disc to the central fovea)

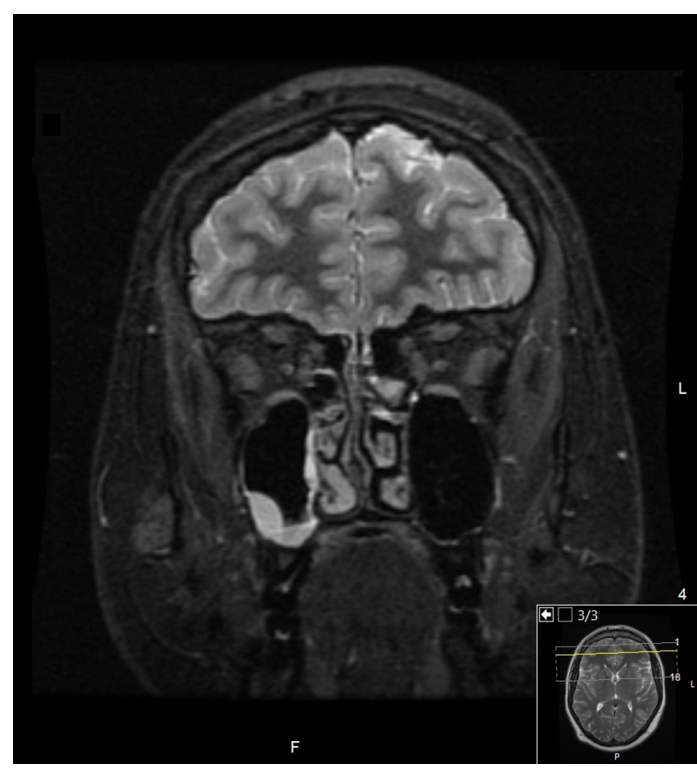

Figure 4 Coronal image of a contrast MRI of the brain and orbits demonstrating bilateral small calibre optic nerves. 


\section{Learning points}

- Optic nerve hypoplasia (ONH) should be considered in the differential of unexplained field loss in the adult patient.

- A thorough taking of the gestational history is mandatory in patients with $\mathrm{ONH}$.

- All patients presenting with ONH must have an endocrinological work-up and an MRI of the brain and orbits.

is useful in determining the severity of the hypoplasia. A ratio below 0.35 is likely to be significant. ${ }^{3}$

$\mathrm{ONH}$ may be unilateral or bilateral and can occur with other ocular, cranial or facial abnormalities. ONH can also be associated with de Morsier syndrome: a triad of optic nerve hypoplasia, pituitary gland dysfunction and absence of the septum pellucidum. All patients diagnosed with optic nerve hypoplasia should have routine endocrinological work-up as the risk of hypothalamic/pituitary dysfunction is $69 \%$ for unilateral cases and $81 \%$ for bilateral cases. ${ }^{1}$ An MRI of the brain and orbits is also indicated as associated neuroimaging abnormalities have been shown in $60 \%$ of patients with $\mathrm{ONH}^{2}$

Contributors All work was undertaken by the corresponding author.

Competing interests None declared.

Patient consent Obtained.

Provenance and peer review Not commissioned; externally peer reviewed.

(c) BMJ Publishing Group Ltd (unless otherwise stated in the text of the article) 2017. All rights reserved. No commercial use is permitted unless otherwise expressly granted.

\section{REFERENCES}

1 Patel L, McNally RJ, Harrison E, et al. Geographical distribution of optic nerve hypoplasia and septo-optic dysplasia in Northwest England. J Pediatr 2006;148:85-8

2 Kaur S, Jain S, Sodhi HB, et al. Optic nerve hypoplasia. Oman J Ophthalmol 2013:6:77-82.

3 Zeki SM, Dudgeon J, Dutton GN. Reappraisal of the ratio of disc to macula/disc diameter in optic nerve hypoplasia. Br J Ophthalmol 1991;75:538-41.

Copyright 2017 BMJ Publishing Group. All rights reserved. For permission to reuse any of this content visit http://group.bmj.com/group/rights-licensing/permissions.

BMJ Case Report Fellows may re-use this article for personal use and teaching without any further permission.

Become a Fellow of BMJ Case Reports today and you can:

- Submit as many cases as you like

- Enjoy fast sympathetic peer review and rapid publication of accepted articles

- Access all the published articles

- Re-use any of the published material for personal use and teaching without further permission

For information on Institutional Fellowships contact consortiasales@bmjgroup.com

Visit casereports.bmj.com for more articles like this and to become a Fellow 